\title{
Soil Erosion Evaluation and Mapping Based on Geomatic Techniques in Wadi EI Malleh Watershed
}

\author{
Abdelkader El Garouani, Prof. \\ Faculty of Sciences and Techniques, Sidi Mohamed Ben Abdellah \\ University, Fez, Morocco \\ Asmaa Nasser Mohamed EID, PhD student
}

Pan African University of Water and Energy Sciences, Tlemcen, Algeria

Omar El Aroussi, Dr.

Avenue Jabrane Khalil Jabrane B.P. 27 - El Jadida 24000, Morocco

doi: 10.19044/esj.2017.v13n18p211 URL:http://dx.doi.org/10.19044/esj.2017.v13n18p211

\begin{abstract}
Soil erosion by water considered is serious problem in the Mediterranean region due to the climate aggressiviness of the mountainous terrain, the traditional farming practices and other anthropogenic pressure on its land and soil. The present study was scheduled to use Geographical Information System (GIS), Remote Sensing data and the Revised Universal Soil Loss Equation (RUSLE) model to evaluate the annual average soil loss and sedimentation rate from Wadi El Malleh watershed, which is located in the Northern-Fez (Morocco), and covers an area of $34 \mathrm{~km}^{2}$. In fact, RUSLE and SEDIMENTATION models were combined with GIS techniques to predict the spatiotemporal distribution of soil erosion and deposition under different land uses. The land use was assessed using the Google Earth image, which was taken in 2013. The image was first geo-referenced and projected into Moroccan coordinates system and classified by ArcGIS software. The use of RUSLE model allowed the estimation of static soil loss. Then the results of RUSLE were applied in the deposition modelling calculations to assess the spread of soil loss downstream by SEDIMENTATION model. The values of the annual net soil erosion obtained by this study were (81.86 $\mathrm{t} / \mathrm{ha} / \mathrm{y})$ in bad land, (-19.19 t/ha/y) in irrigated agriculture areas and (-13.66 $\mathrm{t} / \mathrm{ha} / \mathrm{y}$ ) in reforestation land where the negative values indicated deposition.
\end{abstract}

Keywords: Net soil erosion, RUSLE, SEDIMENTATION, Wadi El Malleh, Morocco 


\section{Introduction}

Soil erosion is a natural phenomenon, occurring throughout the world by the action of water or wind. It causes soil productivity loss as a result of plant removal, fertile topsoil loss, rooting depth reduction, and plant nutrients removal (Merzouk and Dhman, 1998; Gitas et al., 2009). There are many factors which enhance the erosion such as climate change, ecological factors, land use, steep slope and human activities.

Human activities are the main reason for the quickened of the soil erosion. The intensity of soil erosion caused by water is significantly affected by anthropogenic activities that increase or decrease in the land. There are many reasons for quickened erosion including repeated fires and illegal logging and deterioration existing forests, that strongly encourages runoff and leads eventually to severe erosion (Benchaabane, 1997). The cultivation of soil makes it more susceptible to erosion, given the high sensitivity of its physical properties to the types of land use. Lahlou (1994) showed that the destruction of the soil is quite common following the agro-pastoral level operations in the clay and loam soils, which reduces the ability of infiltration and runoff becomes excessive. Note that the effect of the human factor cannot be separated from other effects because its evaluation is complex.

Soil erosion is the master economic and environmental issue that is faced by the dam reservoirs sustainability in the Rif Mountains (North of Morocco). In Wadi El Malleh watershed, an annual soil loss reaches to more than 41 tons per hectare, per year. Hence, the challenges are to involve policy and to provide soil conservation practices to mitigate soil degradation in this area. These challenges increased the need to better understand how to control soil erosion through assessment and mapping of the areas of high risk level and use soil erosion models to highlight the need of soil coverage by active green vegetation and residue in order to enhance watershed management. (Melesse and Jordan, 2002). Therefore, the purpose of this study was to utilize geomatic techniques (GIS and Remote Sensing) to evaluate RUSEL's parameters to predict the annual average soil loss as a result of erosion from Wadi El Malleh watershed.

Water erosion is the focus of this research, it happens naturally as a result of rainfall. By looking at the environmental situation in Morocco, soil conservation and erosion control practices are important for enhancing the current crop production levels. From the other hand, identifying the sensitive areas help to direct the funds needed for erosion control. Erosion estimation models are useful tools in planning for long term land management under agricultural and natural conditions. It is difficult to find a model that deals with all erosion forms, but research is yet progressing and increasingly concentrates on very detailed topics of soil erosion and deposition processes as well as its modelling. 
The Revised Universal Soil Loss Equation (RUSLE) model was developed to estimate water erosion in mild climate; it is easier to adjust to Mediterranean climate than other models. RUSLE model is an empirical based, developed from the Universal Soil Loss Equation (USLE) (Wischmeier and Smith, 1978); however, it is more advanced and has databases not included in the USLE model (Renard et al., 1991). The RUSLE model allows estimation of annual average soil erosion for specific area for identifying management techniques, cropping systems and erosion control practices.

Sediment is the main output of soil erosion due to runoff of surface water. It deposited around the water courses in areas where the river flow are low and geomorphological characteristics are proper for deposition.

\section{Site study description and data set Study Area}

Wadi El Malleh watershed is located in the northern part of Fez in the boundary between Saiss plain and the southern Rif wrinkles (Tghat and Zalagh); it is surrounded by the Wadi Mekkes watershed from the North and West, to Saiss plain from the South and Wadi Sebou valley from the East. It extends over an area of $34 \mathrm{Km}^{2}$ (Fig. 1). The climate is semi-arid with a rainfall annual average of $420 \mathrm{~mm}$. Geologically, the area is characterized by an outcrops of Triassic series of red clay. Several soil types were identified such as: vertisoils, fersialitics, calcimagnesics and poorly evolved soils. The following table summarizes the physical characteristics of Wadi El Malleh watershed.

Table 1: Physical characteristics of Wadi El Malleh watershed.

\begin{tabular}{|c|c|c|c|c|c|c|c|c|}
\hline $\begin{array}{c}\text { Area } \\
\left(\mathrm{Km}^{2}\right)\end{array}$ & $\begin{array}{c}\text { Perim } \\
\text { eter } \\
(\mathrm{Km})\end{array}$ & $\begin{array}{c}\text { Length } \\
\text { of the } \\
\text { trough } \\
(\mathrm{Km})\end{array}$ & $\begin{array}{c}\mathrm{H} \\
\mathrm{max} \\
(\mathrm{m})\end{array}$ & $\begin{array}{c}\mathrm{H} \text { min } \\
(\mathrm{m})\end{array}$ & $\begin{array}{c}\text { Rectangl } \\
\text { e length } \\
(\mathrm{Km})\end{array}$ & $\begin{array}{c}\text { Rectan } \\
\text { gle } \\
\text { width } \\
(\mathrm{Km})\end{array}$ & $\begin{array}{c}\text { Shap } \\
\mathrm{e} \\
\text { inde } \\
\mathrm{x}\end{array}$ & $\begin{array}{c}\text { Drainage } \\
\text { density } \\
\left(\mathrm{Km} / \mathrm{Km}^{2}\right)\end{array}$ \\
\hline 33.85 & 27.64 & 9.42 & 900 & 250 & 10.63 & 3.59 & 1.33 & 2.74 \\
\hline
\end{tabular}

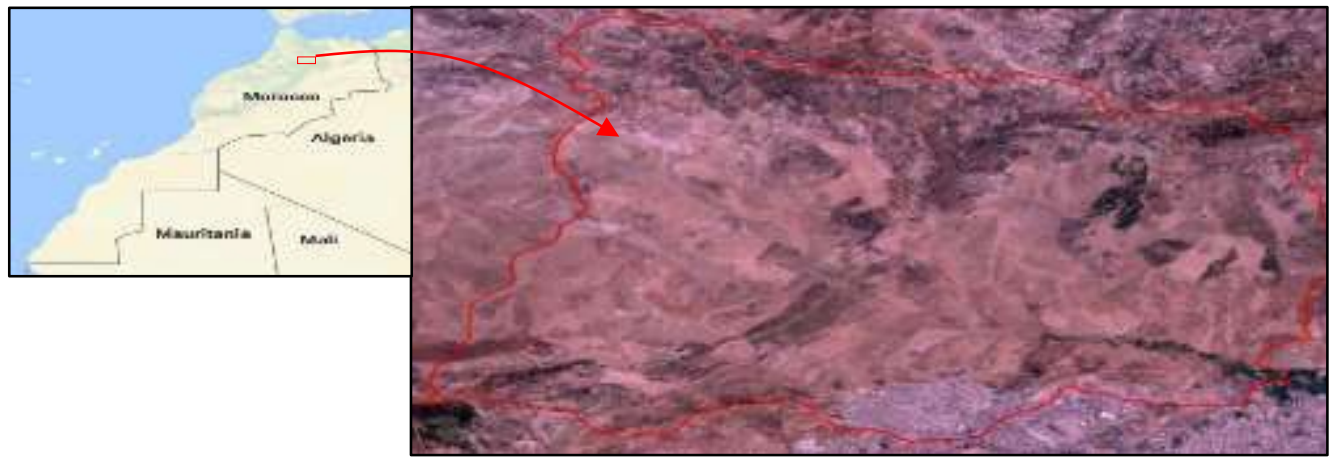

Figure 1: Geographic situation of Wadi El Malleh watershed 


\section{Data Set}

Soil erosion process is directly affected by several factors such as, precipitation, land cover, land use, pedology and topography of the watershed. To estimate the soil erosion and sediment deposition ratio in Wadi El Malleh watershed, the following dataset were required.

\section{Digital elevation model}

The Digital Elevation Model (DEM) of Wadi El Malleh watershed is presented in Figure 2. With a spatial resolution of $30 \mathrm{~m}$ x $30 \mathrm{~m}$, this DEM is derived from the Advanced Spaceborne, Thermal Emission and Reflection Radiometer (ASTER), Globaligital Elevation Model Version 2 (GDEM V2), released on October 17, 2011. In geomorphological analyses DEM representing the elevation in terms of topographic surface is essential (Schmidt, 2000).

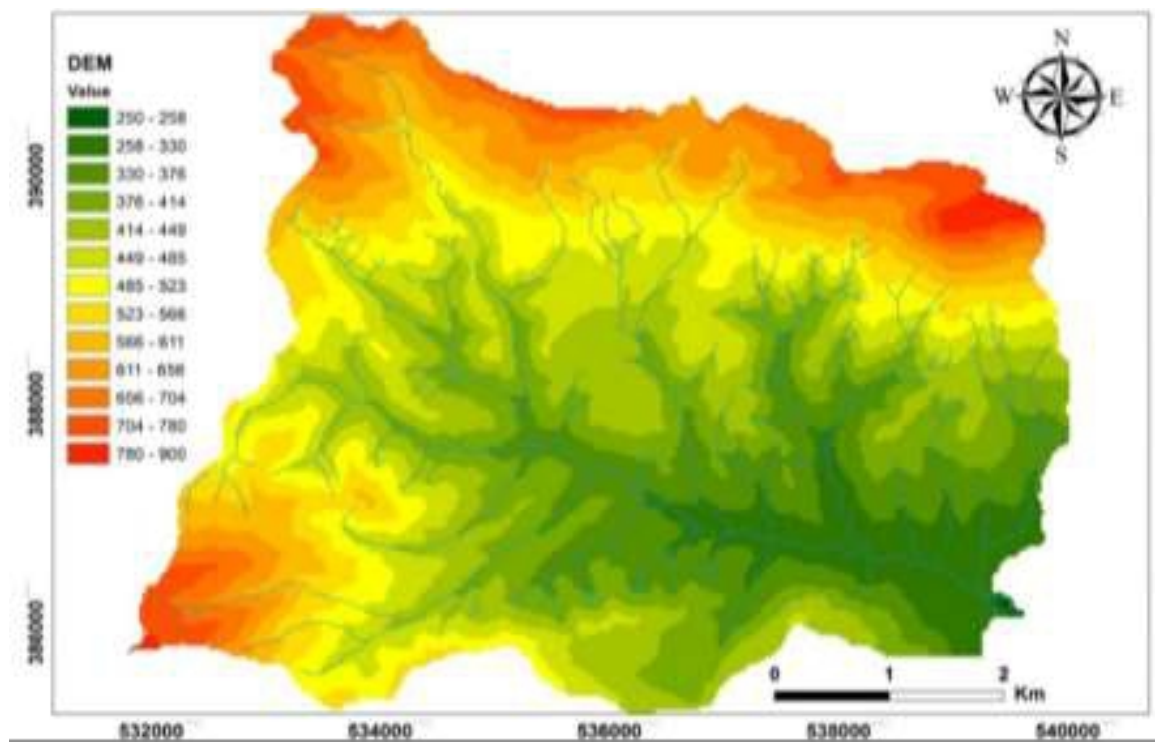

Figure 2: Digital Elevation Model of Wadi El Malleh watershed.

\section{Land Use}

The identification of the spatial variation of the land use in the study area was carried out from the photo interpretation of a Google Earth image, which taken in 2013. Google Earth provides freely accessible images with high spatial resolution which can be used to identify land use in a region, especially for areas with high numerous landscapes. Google Earth can estimate the spatial distribution of natural disaster mapping and evaluate land use maps. The image was first geo-referenced and projected into the Moroccan coordinates system and classified by Arc GIS 10.3. From the 
previous perceptions, land use map has been performed based on agriculture land use and soil characteristics references obtained from the field.

The photo interpretation method is used for land use classification; interpreted points were classified into 9 classes (Bad land, Cereal, Dump, Olive, Olive + Cereal, Irrigated agriculture, Reforestation, Raw land and Urban) (Fig. 3).

The dynamics of land use showed that the study area is experiencing expansion of uncultivated land to the detriment of reforestation areas. The presence of urban areas in the fields of agriculture shows an intrusion of the local population with the consequent degradation of natural resources.

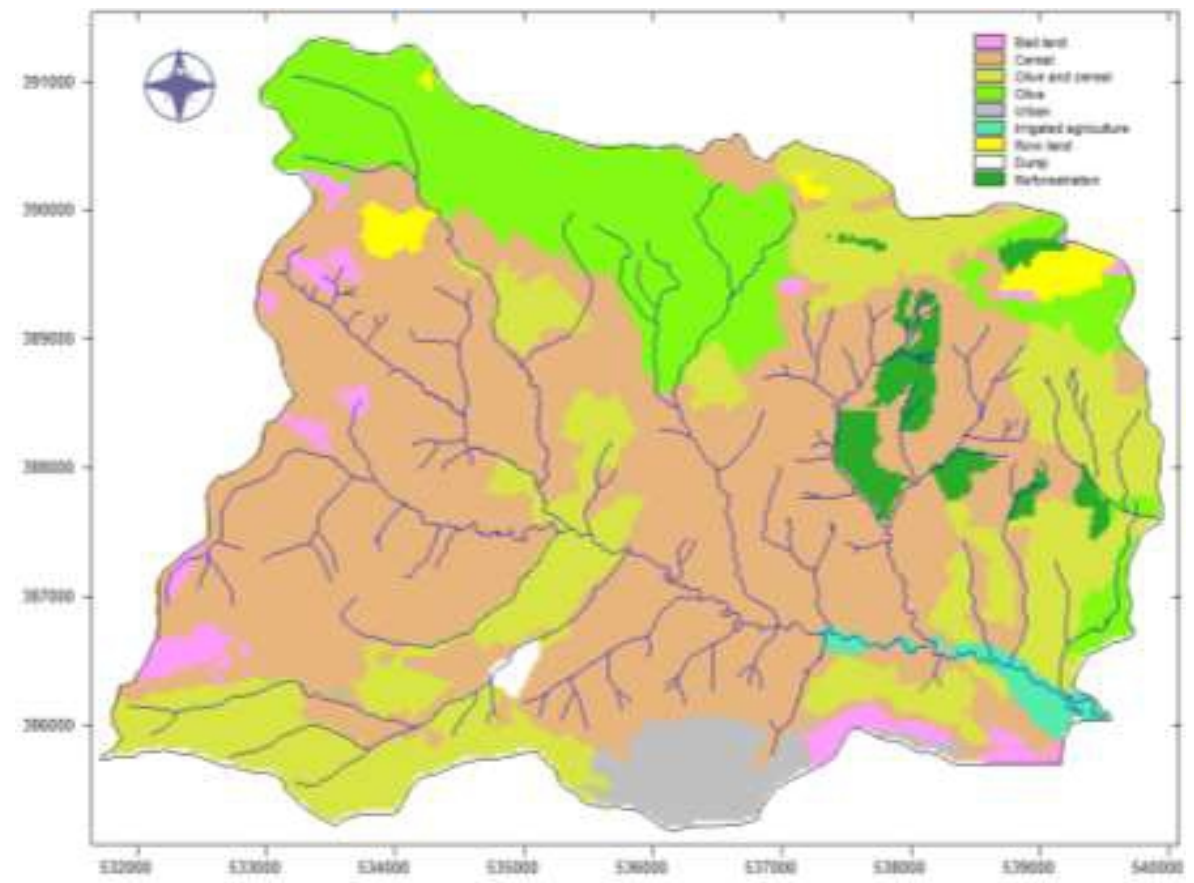

Figure 3: Land use map of Wadi El Malleh watershed (2013)

The following table represents the land use classification condition of Wadi El Malleh watershed in 2013. As shown in the land use map, cereal is the most widespread category in Wadi El Malleh watershed followed by olive and cereal, while dump, is the least spreading category (Table 2).

Table 2: Land use classification of Wadi El Malleh watershed in 2013

\begin{tabular}{|c|c|c|}
\hline Category & Area (Hectares) & $\%$ \\
\hline Bad land & 86.26 & 2.52 \\
\hline Cereal & 1799.38 & 52.54 \\
\hline Olive and Cereal & 736.93 & 21.52 \\
\hline Olive & 511.89 & 14.95 \\
\hline Urban & 103.80 & 3.03 \\
\hline Irrigated agriculture & 38.87 & 1.13 \\
\hline
\end{tabular}




\begin{tabular}{|c|c|c|}
\hline Row land & 45.88 & 1.34 \\
\hline Dump & 9.76 & 0.29 \\
\hline Reforestation & 91.95 & 2.68 \\
\hline
\end{tabular}

\section{Soil parameters measurements}

Soil infiltration rate is used to determine the soil permeability in the region. It is usually estimated from field data. The permeability measurements have been done to estimate the infiltration rate using the double ring-infiltrometer (Muntz method) (Mathieu et al., 2000). The soil texture measurements used to predict various particle sizes (sand, silt or clay) by calculating the grain size to estimate the grain size classes using the soil texture triangle. The soil humidity of the watershed was estimated and varied from 5.1 to $14.8 \%$. The bulk density and soil porosity was determined and varied from $\left(0.49\right.$ to $\left.0.66 \mathrm{~g} / \mathrm{cm}^{3}\right)$ and $(75.09$ to $81.51 \%)$, respectively. The measured organic matter varied from 1.4 to $14.1 \%$.

\section{Soil Erosion Modelling \\ Model concept}

Soil erosion modelling use mathematical equations which requires many data measurements as well as physical description of the erosion phenomena. The data measurements are important to estimate the inputs data and to legalize the model. The physical description utilises to identify the main variables which formulate the quantitative mathematical relations of the erosion process (Merritt et al., 2003).

Different approaches have been developed to assess the risk of water erosion. However, we can distinguish qualitative approaches based on expertise and quantitative approaches. Scientists around the world are not only interested in determining the amount of soil loss caused by soil erosion using different models but also to predict the impact on the population around the affected areas. Erosion models are used to determine the processes of detachment, transport and deposition of eroded soil (Renschler and Harbor, 2002).

The Revised Universal Soil Loss Equation (RUSLE) is empirically based equation, which assumes that the detachment, transport and deposition are related to the sediment content of the flow (Renard et al., 1997; Pitt, 2007). It has been derived from huge amount of field data, addresses the sheet and rill erosion and simulate climate change, land use change that could affect soil loss. The RUSLE model is worldwide accepted as reliable, effective and accurate method for identifying the spatial pattern of soil erosion within large regions which makes it possible to identify the most impacted catchments or areas by soil loss. The RUSLE equation is as follows: 
Where:

$$
A=R . K . L . S . C . P
$$

$\mathrm{A}=$ average annual soil loss(tons ha-1 year-1),

$\mathrm{R}=$ rainfall erosivity factor (MJ mm ha-1 year-1),

$\mathrm{K}=$ soil erodability factor (tons ha $\mathrm{MJ}-1 \mathrm{~mm}-1$ ),

$\mathrm{L}=$ slope length factor $(\mathrm{L} / \mathrm{L}) \mathrm{m}$,

$\mathrm{S}=$ slope steepness factor (percent),

$\mathrm{C}=$ vegetation cover management factor (dimensionless), and

$\mathrm{P}=$ supporting (conservation) practices (dimensionless) (Renard et al. 1997).

The RUSLE equation can be divided into two parts according to its variables: a) Management variables which include $\mathrm{P}$ and $\mathrm{C}$ factors, which may change over time; b) Environmental variables include the R, S, K and L factors, which stay constant over time (Hickey et al., 2005).

GIS applications in soil erosion prediction are increasing daily. There are various examples for the integration of GIS with erosion models: De Roo (1989) linked ANSWERS with GIS, Bonn (1998) linked USLE with GIS and El Garouani et al (2007) linked RUSLE with GIS.

\section{RUSLE parameters estimation and mapping}

To achieve the objectives of this study that seeks mainly to the quantification of the water erosion in the watershed of Wadi El Malleh, an exploration of the physical environment has been made firstly through field studies. After that spatial distribution of water erosion has been conducted by looking at the parameters that enhance the erosive dynamics. The applied methodology involved collecting, analysing and spatial processing of data of land use, physical constraints and geomorphology of Wadi El Malleh watershed. Hence, thematic informations have been extracted from satellite images and other data such as: the digital elevation model and soil measured parameters. Here below follows the presentation of method of determination of all the required parameters for the RUSLE and SIDEMENTATION SEDIMENTATION models.

\section{$\mathbf{R}$ factor (Rainfall erosivity)}

The evaluation of $\mathrm{R}$ is based on the formula of Arnoldus (1980) that reflects the monthly and annual rainfall in $\mathrm{mm}$ in 5 stations surrounding Wadi El Malleh watershed (Table 3).

Where

$$
R=1.753 * 10\left(1.5 \log \left(P_{i}^{2}\right) / P\right)-0.8188
$$

$\mathrm{R}$ is the average value of the annual index of aggressiveness

$\mathrm{P}$ is the average annual precipitation in $\mathrm{mm}$.

$\mathrm{Pi}$ is the average monthly precipitation in $\mathrm{mm}$. 
Table 2: The R-value results

\begin{tabular}{|c|c|c|c|c|c|}
\hline Station & Fes Sais & Dar Arsa & Bridge \\
$1987 / 2014$ & $\begin{array}{c}\text { Sebou } \\
1979 / 2014\end{array}$ & $\begin{array}{c}\text { Sidi Chahed } \\
1994 / 2014\end{array}$ & $\begin{array}{c}\text { DRH Fes } \\
1981 / 2014\end{array}$ \\
\hline R Value & 70.79 & 72.08 & 60.52 & 71.09 & 71.36 \\
\hline R Average & \multicolumn{5}{|l}{69.17} \\
\hline
\end{tabular}

K factor (Soil erodibility)

To determine the $\mathrm{K}$ factor in Wadi El Malleh watershed, samples were collected from several soil units made in the basin and various $\mathrm{K}$ values for each collected sample were determined. The $\mathrm{K}$ factor has been calculated by the Wischmeier Nomograph and its formula to check the results (Wischmeier et al., 1971). The results of the $\mathrm{K}$ factor varies from 0.07 determined on the limestone formations at Zalagh mountain to 0.58, determined on bad land in the West of Wadi El Malleh watershed (Table 4). The $\mathrm{K}$ factor distribution map thus matches that of the pedology and lithology of the watershed (Fig. 4).

Table 4: K factor values in the watershed of Wadi El Malleh.

\begin{tabular}{|c|c|c|c|c|c|c|c|c|c|c|c|c|}
\hline $\begin{array}{c}\text { Pedologi } \\
\text { c unite }\end{array}$ & 1 & 2 & 3 & 4 & 5 & 6 & 7 & 8 & 9 & 10 & 11 & 12 \\
\hline $\mathrm{K}$ & 0.1 & 0.5 & 0.3 & 0.0 & 0.3 & 0.3 & 0.1 & 0.5 & 0.1 & 0.2 & 0.5 & 0.1 \\
8 & 3 & 6 & 7 & 6 & 5 & 8 & 8 & 2 & 6 & 3 & 7 \\
\hline
\end{tabular}

According to the classification of Bolline \& Rousseau in 1978 :

$\mathrm{K}<0.1$ Soils very resistant to erosion

0.1 to 0.25 Soil fairly resistant to erosion

0.25 to 0.35 Soils moderately sensitive to erosion

0.35 to 0.45 Sols very sensitive to erosion

over 64\% of the watershed area of Wadi El Malleh, the soils are in the class quite resistant to erosion, while soil class quite sensitive to erosion dominates $35 \%$ of the region.

\section{LS factor (Slope length)}

The biggest relief parameters which determine the intensity of the water erosion in the watershed are the gradient and slope length. The combined effect of the gradient of the slope and its length is taken up by the topographic factor (LS) (Roose, 1994). The calculation of this factor is performed using the IDRISI Selva software from the DEM with a resolution of $30 \mathrm{~m}$.

\section{C factor (Cover management)}

Despite the number of experimental studies that have been made in Morocco on the quantification of erosion by USLE or RUSLE, there is still a 
lack of experimental $\mathrm{C}$ factor for different types of plants. For the determination of C-factor values in Wadi El Malleh Watershed, the values have been extracted from the work done in the Rif by (Kalman, 1967). The values assigned to different land use patterns for the watershed of Wadi El Malleh, are between 0.04 and 0.75 (Fig. 5).

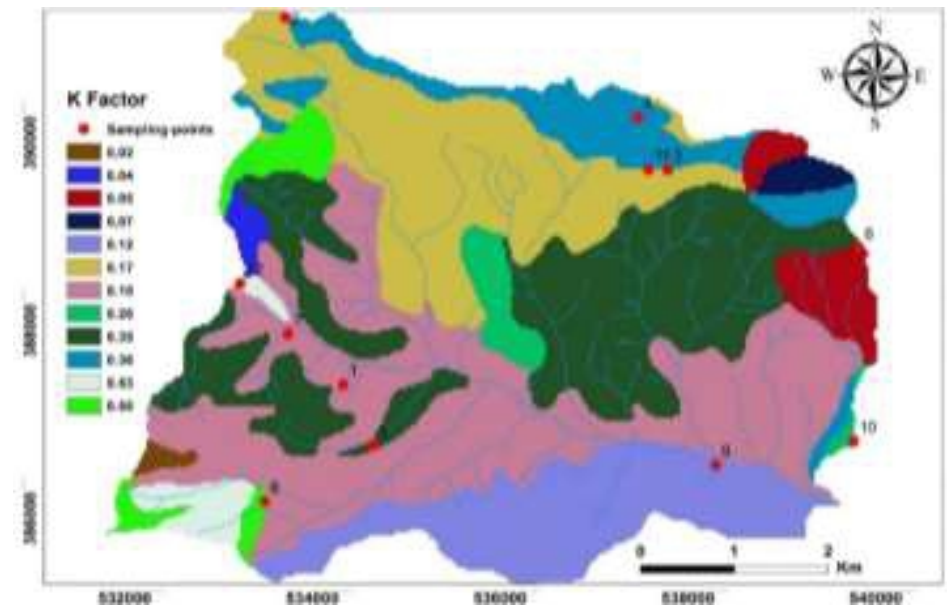

Figure 4: Map of Soil Erodibility Factor

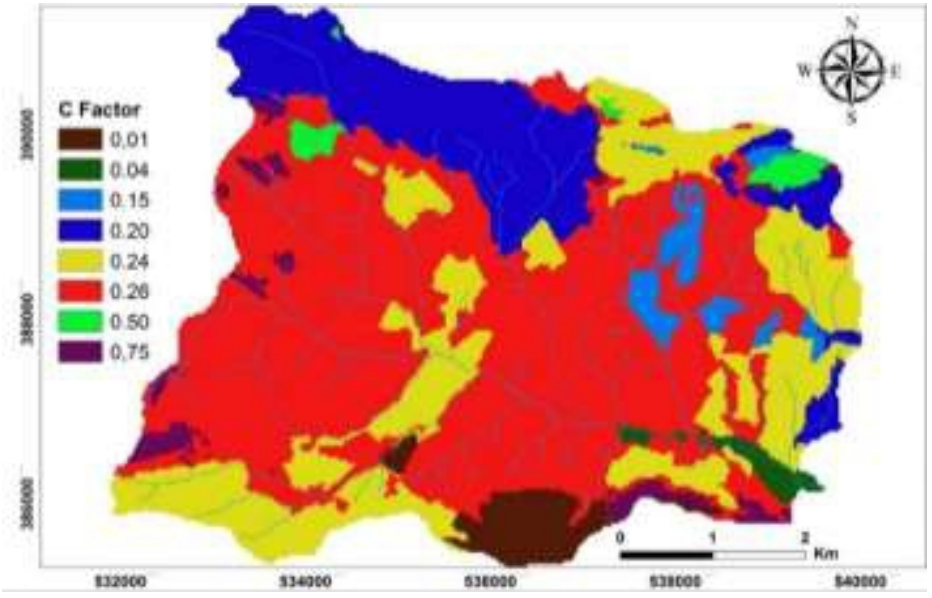

Figure 5: Map of $\mathrm{C}$ factor values

\section{P factor (Supporting practices)}

Factor expressing the protection of soil from agricultural practices, erosion control practices of soil (P) says human intervention in creating practices that conserve soil and reduce land degradation, such as crops curves level in alternating strips or terraces, reforestation benches, mounding and ridging are the most effective soil conservation practices. The value of $\mathrm{P}$ $=1$ is given to the land on which none of the cited practices are used. $\mathrm{P}$ 
values less than or equal to 1 when there is intervention to fight against erosion. Across the watershed of Wadi El Malleh, there is no anti-erosion development, and farmers do not use conservation tillage practices. Crops are mainly grain and blowing is rarely parallel to contour lines. For all these reasons, we assigned the value $\mathrm{P}=1$ for the entire basin area.

After determining all factors for RUSLE model, we introduced all these parameters in an integrated module in Idrisi Selva software.

\section{Annual average soil loss rate by RUSLE model}

The soil erosion occurrence is closely related to the land use situation, the cover management status, the slope length and the slope steepness. In order to estimate the annual average soil loss rate in Wadi El Malleh watershed, the six factors of the RUSLE model are integrated in RUSLE module in the Idrisi Selva software. This module not only calculates the soil loss for each pixel of the grid but also the group pixels into homogeneous polygons (patches). (Eastman, 2006; El Garouani et al., 2009).

The figure 6 shows the annual average soil loss rate. The annual average soil loss rate of Wadi El Malleh watershed is between 0 and 294 tons/year (Eid et al., 2016).

The resulted annual average soil loss rates determined by RUSLE by type of land use were between (0.760 to $294.41 \mathrm{t} / \mathrm{ha} / \mathrm{y})$ which consider a minimum annual average soil loss value in the urban areas followed by $(5.726 \mathrm{t} / \mathrm{ha} / \mathrm{y})$ in the irrigated agriculture areas and a maximum annual average soil loss value reported at the bad land. The watershed topography characterize by steep slopes, which resulted in vulnerability to severe erosion at most of the watershed areas and caused sediment deposition.

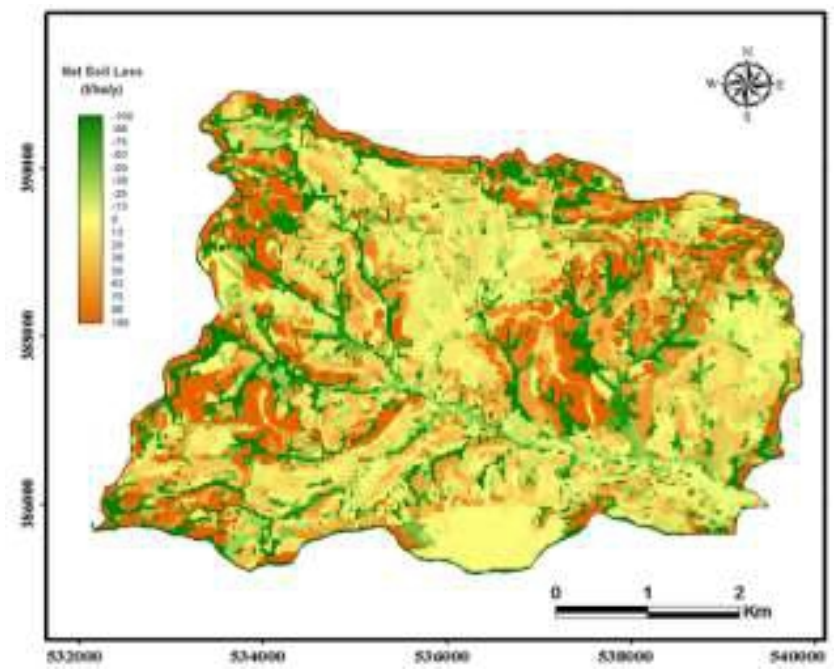

Figure 7: Annual average soil loss map of Wadi El Malleh watershed (by RUSLE) 


\section{Net Soil Loss by Sedimentation Model}

Sedimentation model is based on the results of RUSLE model, used to calculate the erosion balance in each patche. It uses results from the calculation of RUSLE model to assess the net movement of soil (erosion or deposition) in patches (Lewis et al., 2005). The unit first determines the average altitude for each patche and the location of the highest altitude in the catchment area or in the relevant field. The direction of movement of the soil is then determined by the relative differences in altitudes between adjacent polygons. So the movement is always in the direction of the downward slope. The amount of soil loss that goes into the surrounding lower polygon is proportional to the length of the common border between the top polygon and one below. Negative values indicate a deposit and positive values mean erosion.

For example, the proportional soil loss of Patch A (the higher one) to lower patch B is $1 \mathrm{t} \mathrm{yr}^{-1}$. Patch B is initial RUSLE computed soil loss is $3 \mathrm{t}$ $\mathrm{yr}^{-1}$. Thus, the net soil loss of Patch B is calculated by the SEDIMENTATION module as the difference between the amount of sediment transported into the patch and the patch's RUSLE soil loss value. In the previous example, $3 \mathrm{t} \mathrm{yr}^{-1}$ (B) $-1 \mathrm{t} \mathrm{yr}^{-1}$ (A) results in a net soil loss for Patch B of $2 \mathrm{t} \mathrm{yr}^{-1}$ (Fig. 7a). Similarly, if Patch C located downslope from Patch $\mathrm{B}$, has an estimated soil loss of $2 \mathrm{t} \mathrm{yr}^{-1}$, its net deposition will be $1 \mathrm{t} \mathrm{yr}^{-}$ ${ }^{1}$ (Fig. 7b).

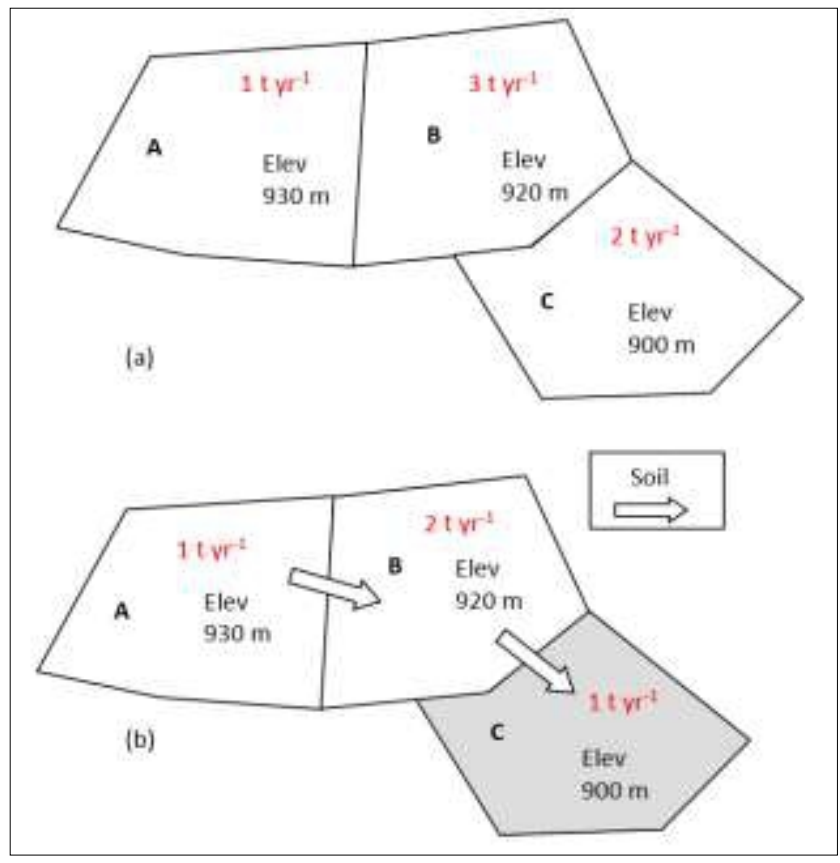

Figure 7: a) Patches with estimated RUSLE soil loss values, b) net soil loss/deposition (shaded grey) 
If the data are analysed throughout the watershed, a report from the issuance of the sediment can be entered to determine the amount of sediment out of the basin. The implementation of this model will come after that of RUSLE. It requires the digital terrain model (DTM) and patches identifying images and that of soil losses resulting from the calculation made by RUSLE (Fig. 6).

The results of calculations of net soil loss are presented in figure 8 . The technique allows the evaluation of the net erosion in the basin scale and identifying areas that need interventions to fight against land degradation.

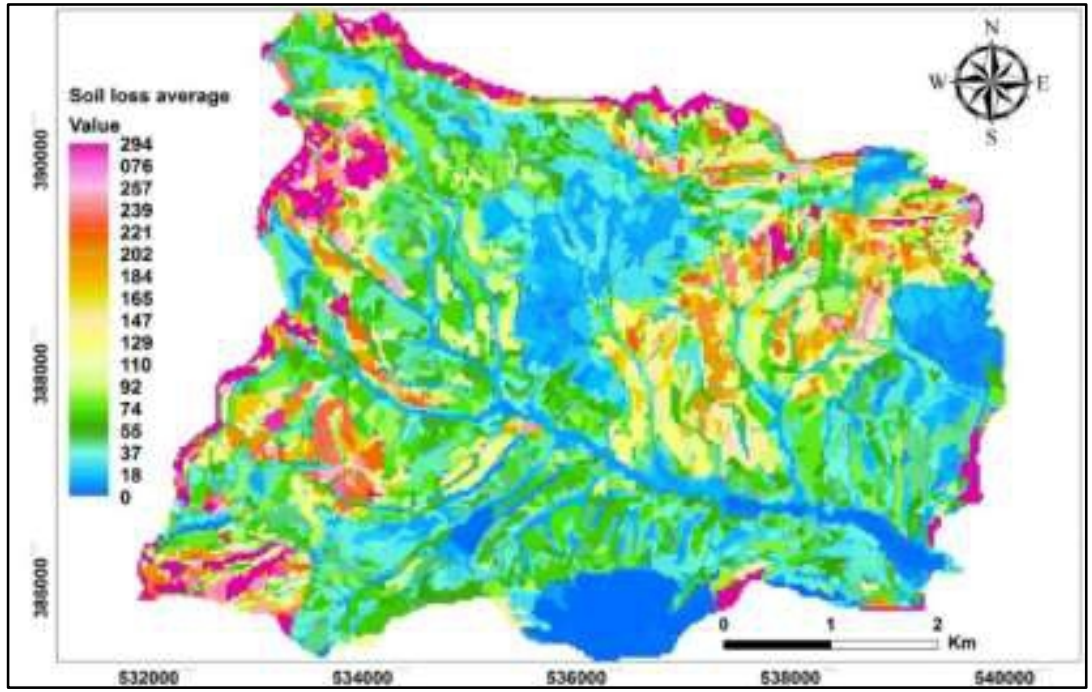

Figure 8: Net annual soil loss map for Wadi El Malleh watershed

By analysing the map of the spatial distribution of soil loss calculated by the sedimentation model, we find that the areas most sensitive to erosion are located in the South and Southwest of the basin and are characterized by soil silt-sandy clay texture.

A great fragility of the East and South-East part of the basin consists mainly of marl and sandstone of Miocene marl (up to $50 \mathrm{t} / \mathrm{ha} /$ year). About $1150 \mathrm{ha}$, or $9.5 \%$ of the total basin area. The low erosion rates $(<7 \mathrm{t} / \mathrm{ha} / \mathrm{year})$ mainly dominate the slopes of the right bank of the pond where the dominance of arable land and olive trees cover the sandy terrain. The areas of low soil loss or deposition correspond to areas of low slope or plains (up to $50 \mathrm{t} /$ year/ha). Table 5 summarises the net soil loss by land use type.

From this map we can make out the priority areas to receive the facilities, and we can conclude that land use is the parameter on which the management actions of the territory must rely for limiting sensitivity to erosion. 
Table 5: Net annual soil loss (NASL) for Wadi El Malleh watershed.

\begin{tabular}{|c|c|c|c|c|}
\hline Land Use & Area (ha) & NASL (t/ha/y) & NASL (t/field/y) & $\%$ \\
\hline Bad land & 86.26 & 81.86 & 7061.40 & 2.52 \\
\hline Reforestation & 91.95 & -13.66 & -1255.62 & 2.68 \\
\hline Cereal + Olive & 736.93 & 7.37 & 5433.62 & 21.52 \\
\hline Cereal & 1799.36 & -1.13 & -2041.12 & 52.54 \\
\hline Irrigated agriculture & 38.86 & -19.19 & -745.65 & 1.13 \\
\hline Raw Land & 45.88 & 41.33 & 1896.24 & 1.34 \\
\hline Olive & 511.89 & 5.27 & 2697.64 & 14.95 \\
\hline Urban & 113.56 & -4.94 & -561.29 & 3.32 \\
\hline
\end{tabular}

\section{Conclusion}

The study area is characterized by a semi-arid climate and marked by heterogeneity of precipitation, due to its position in the Rif Mountains. The dominance of impermeable bedrock, makes most of the precipitated water sheet runoff. Soil distribution depends on topography, the nature and importance of the vegetation cover and the rock nature.

The study aimed at estimatement of the spatial distribution of soil loss and to analyse the effect of slope exposition and land use on soil erosion. A quantitative approach was used in this study to evaluate soil erosion risk. Soil erosion hazard mapping made by application of GIS based models with parameters derived from remote sensing data. After mapping of land use, soil losses were estimated. SEDIMENTATION model which uses the results of the calculation of RUSLE model was integrated in Idrisi to assess the net movement of soil erosion or deposition in patch.

Urban land, reforestation and olive trees cover more than $42.5 \%$ of the area of land studied with remarkable extension of uncultivated land. Approximately $62 \%$ of the basin area is dominated by soil units very sensitive to water erosion namely vertisols. With existing production systems, 4\% (132 ha) of catchment shows a water erosion of soil that exceeds the acceptable threshold of (11.5 t/ha/y) generally accepted, especially on bare soils and bad land.

\section{References:}

1. Arnoldus, H.M.J. (1980). Methodology used to determine the maximum average soil loss due to sheet and rill erosion in Morocco. Bulletin FAO, $\mathrm{n}^{\circ}$ 34, p. 39-48.

2. Benchaabane, A. (1997). Impact de l'exploitation du prélèvement du bois de feu sur l'érosion du sol en haute montagne (cas du huat aTlas de Marrakech, Maroc). 8(4), 13-21.

3. Bonn F. (1998). La spatialisation des modèles d'érosion des sols à l'aide de la télédétection et des SIG : Possibilités, erreurs et limites», Sécheresse, Vol. 9, n³, p. 185-192. 
4. Bolline A., P. R. (1978). erodibility average soils and high Belgium. Using a method of calculating the $\mathrm{K}$ factor of the universal equation of soil loss. pp. 127-140.

5. De Roo, A. (1996). Soil erosion assessment using GIS. In Geographical information systems in hydrology (pp. 339-356). Dordrecht; Boston: Kluwer Academic Publishers.

6. Eastman, J.R. (2006). Manual Idrisi Andes: Guide to GIS and image processing. - Worcester, MA: Clark

7. Eid Nasser M. A., El Garouani A., El Aroussi O. and Chabane Sari S.M. (2016). Evaluation of soil erosion and deposition process by using Geographical Information System and Remote Sensing in Oued El Maleh Watershed (Morocco). $5^{\text {ème }}$ Colloque International du réseau "Eaux \& Climats", Fès, le 12 - 13 Octobre 2016. Fès, Maroc

8. El Garouani, A., Chen, H., Lewis, L., Tribak, A., \& Abahrour, M. (2009). Cartographie de l'utilisation du sol et de l'érosion nette à partir d'images satellitaires et du SIG Idrisi au Nord-Est Marocain. Télédétection, 8(3), 193-201.

9. El Garouani A., Chen H., Lewis L.A., Tribak A. et Abahrour M. (2007). Apport de la Télédétection et du SIG dans le suivi spatiotemporel de l'occupation du sol et de l'érosion nette dans le bassin de l'Oued Tlata (Maroc). Journées Scientifiques inter-réseaux : Gestion intégrée des eaux et des sols ressources, aménagements et risques en milieux ruraux et urbains, 4 - 9 novembre 2007, Hanoi, Vietnam

10. Gitas, I. Z., Douros, K., Minakou, C., Silleos, G. N., \& Karydas, C. G. (2009). Multi-temporal soil erosion Risk assessment in N. Chaldiki using modified USLE raster model. EARSel eProceedings, $8(1), 40-52$.

11. Heusch, B., Kalman, R., Duhamel, P. L., \& Robert, P. (1970). Erosion, transport solide, sédimentation. Etude sur l'erosion, 10, 390.

12. Hickey, R., Burns, E., Bolte, J., \& Walker, D. (2005). Development of a statewide erosion vulnerability screening tool for Oregon. Retrieved June 2016, from http//www.siue.edu/geography/online/Hickey05.pdf

13. Kalman, R. (1967). Essai d'évaluation pour le pré-Rif du facteur couverture végétale de la formule de Wischmeier de calcul de l'érosion. Rapport, Rabat, $12 \mathrm{p}$.

14. Lahlou, A. (1994). Envasement des barrages au Maroc. SMD Wallada, Maroc.

15. Lewis A.L., Verstraeten G., Zhu H., (2005). RUSLE applied in a GIS framework: Calculating the LS factor and deriving homogeneous patches for estimating soil loss. International Journal of Geographical Information Science, 19 (7), August 2005: pp. 809-829. 
16. Mathieu C., Pieltain F., Asseline J., Chossat J.C. et Valentin CH. (2000). Analyse des sols : Méthodes choisies. Editeur Lavoisier, Paris, $251 \mathrm{p}$.

17. Melesse, A. M., \& Jordan, J. D. (2002). A comparison of fuzzy vs. Augmented-ISODATA classification algorithms for cloud-shadow discrimination from Landsat images. $J$ of Photogrammetry Engineering and Remote Sensing, 68, 905-911.

18. Merritt, W. S., Letcher, R. A., \& Jakeman, A. J. (2003). A review of erosion and sediment transport models. Environmental Modelling \& Software, 18(8), 761-799.

19. Merzouk A. and Dhman H. (1998). Shifting land use and its implication on sediment yield in the Rif Mountains (Morocco). Advances in Geo Ecology, 33, pp. 333-340.

20. Pitt, R. (2007). Erosion Mechanisms and the Revised Universal Soil Loss Equation (RUSLE). In R. Pitt, Construction Site Erosion and Sediment Controls, Planning, Design and Performance.

21. Renard, K. G., Foster, G. R., Weesies, G. A., \& Porter, J. P. (1991). RUSLE: revised universal soil loss equation. Soil and Water Conservation, 46(1), 30-33.

22. Renard, K. G., Foster, G. R., Weesies, G. A., McCool, D. K., \& Yoder, D. C. (1997). Predicting Soil Erosion by Water: A Guide to Conservation Planning with the Revised Universal Soil Loss Equation (RUSLE) (Vol. 703). Washington: U.S. Department of Agriculture.

23. Renschler, C. S., \& Harbor, J. (2002). Soil erosion assessment tools from point to regional scales-the role of geomorphologists in land management research and implementation. Geomorphology, 47(2), 189-209.

24. Roose E. (1994). Use of the universal soil loss equation to predict erosion in west Africa. SCSA, special publication, n 21: pp.60-74.

25. Schmidt, J. E. (2000). Comparison of polynomial models for land surface curvature calculation. Int. J. Geographical Inf. Sc., 17, 797814.

26. Wischmeier, W. H., \& Smith, D. D. (1978). Predicting rainfall erosion losses. In A guide for conservation planning (pp. 1-537). Washington: U.S. Department of Agriculture.

27. Wischmeier, W. H., Johonson, C. B., \& Cross, B. V. (1971). Soil erodibility nomograph for farmland and construction sites. Journal of soil and water conservation, 26, 189-192. 